\title{
Comparing rhythm in speech and music: The case of English and Polish
}

\author{
Mateusz Jekiel \\ Faculty of English, Adam Mickiewicz University, Poznań \\ mjekiel@wa.amu.edu.pl
}

\begin{abstract}
The point of departure for the following study is Patel and Daniele (2003), who suggested that the rhythm of a culture's language is reflected in its instrumental music. The former study used the normalised pairwise variability index (henceforth nPVI), a measure of temporal patterning in speech, to compare the variability of vocalic duration in recorded speech samples with the variability of note duration in music notation on the example of English and French speech and classical music. The aim of this experiment is to test whether the linguistic rhythm conventionalised in the language of a community affects the rhythm in the musical practice of that community, by focusing on English and Polish speech and classical, as well as folk music. The nPVI values were obtained from a set of English and Polish recorded news-like sentences, and from musical notation of English and Polish classical and folk musical themes. The results suggest that reflections of Polish speech rhythm may be more apparent in folk music than in classical music, though more data are needed to test this idea. This initial study suggests that the method used might bring more fruitful results when comparing speech rhythm with less formalized and more traditional musical themes.
\end{abstract}

Keywords: speech rhythm; musical rhythm; nPVI; English; Polish.

\section{Introduction}

\subsection{Language and music}

Although the relationship between language and music has been widely studied by linguists and musicologists alike (e.g. Wenk 1987; Mithen 2005; Patel 2008), there is still a scarcity of quantitative studies that would examine the extent of the relationship between those two domains. Indeed, the transfer between linguistics and musicology is not a novelty: linguists have often borrowed musicological concepts in prosodic theories (Liberman 1975), while musicologists 
have used tools from linguistic works (Lerdahl and Jackendoff 1983). However, there are few interdisciplinary studies that examine the exact scope of the parallelism between language and music.

There are a number of reasons for approaching the topic of language and music. According to Nettl (2000), both appear in every society, regardless of the presence or absence of other forms of culture, such as writing, painting or sculpture. Applying an evolutionary perspective to this debate, many scholars, (e.g. Wallin et al. 2000; Mithen 2005) argue that human minds are shaped for music by natural selection, as originally proposed by Darwin (1871). Mithen (2005) points out that there might have existed a "proto-music-language" among Neanderthals, suggesting the co-evolution of language and music. Finally, according to Patel (2008: 4), both prosodic and musical processes share resources at specific neural levels, including forming learned sound categories, deriving regular patterns from rhythmic sequences and combining elements into syntactic structures. Therefore, there is a firm basis for studying the relation between language and music. However, it is still difficult to ascertain which subfield in particular (e.g. rhythm, melody, syntax) will prove the most vital in this debate.

\subsection{Linguistic and musical rhythm}

When studying rhythm in language and music, it is crucial to point out that there is still no universally accepted definition of rhythm. For the purpose of this paper, we will recall two key definitions. The first, proposed by Dellwo (2006), defines rhythm as a "systematic organisation of prominent and less prominent speech units in time", where by "speech units" we mean syllables or vocalic intervals, while by "prominence" we mean higher duration, intensity or frequency. The second definition, suggested by Patel (2008: 96), describes rhythm as "the systematic patterning of sound in terms of timing, accent, and grouping". While the former definition, dealing only with speech units, is more specific, the latter is more neutral and can be used for analysing both linguistic and musical rhythm.

Another reason for studying rhythm across these two domains is the question of whether musical rhythm is an offshoot of linguistic rhythm (Patel 2006: 99). This hypothesis is based on the fact that both speech and music patterns feature rich rhythmic organization, share similar group boundary markings (e.g. pitch, duration) and use similar brain substrates for speech and music perception. However, Patel also points out that beat perception and synchronization are 
specific to musical rhythm and do not apply to linguistic rhythm. Therefore, not all musical rhythm is an offshoot of linguistic rhythm.

Although some studies point out the connection between linguistic and musical rhythm (e.g. Selkirk 1984; Handel 1989), there is still a scarcity of empirical tools for analysing the degree of this relationship. One hypothesis that requires empirical evidence is a claim held by a number of linguists and musicologists (e.g. Abraham 1974; Wenk 1987) that the prosody of a composer's language can influence his or her instrumental music. This argument was the point of departure for Patel and Daniele (2003), where by applying the nPVI measurements and comparing the variability of vocalic durations in recorded speech with note durations in music notation, they conclude that the different linguistic rhythms of English and French are mirrored in the music of English and French classical composers of the 19th century.

This method was also applied in a relatively recent work by McGowan and Levitt (2011), who argue that rhythmic characteristics of speech and music can be also correlated on a dialectal level. The similarities found in their study between recordings of unscored musical themes and spontaneous speech of musicians from specific regions (the Shetland Islands, Scotland; County Donegal, Ireland; and the state of Kentucky) who performed them, add to the body of empirical work initiated by Patel and Daniele, suggesting that the relationship between linguistic and musical rhythm can be made evident not only through cross-linguistic but also through cross-dialectal comparisons.

\subsection{The $\mathrm{nPVI}$}

The nPVI was originally developed to analyse rhythmic differences between stress-timed and syllable-timed languages. This classification was introduced in Pike (1945) and investigated further in Abercrombie (1967), where stress-timing defines languages having patterns of equal duration between stressed syllables (primarily Germanic languages, e.g. English, German, Dutch), while syllabletiming describes languages having syllables of equal duration (primarily Romance languages, e.g. French, Italian, Spanish). This classification is disputed in Dauer (1983), who argues that stress-timing or syllable-timing is not an absolute, but rather a gradient feature, allowing languages to be described as more or less stress-based. Moreover, Dauer claims that rhythmic diversity results from a combination of phonological, phonetic, lexical and syntactic features, where syllable structure, vowel reduction and word stress are of prime importance. Fi- 
nally, Nespor (1990) concludes that neither a dichotomous nor a continuous classification system can adequately account for the rhythmic properties of rhythmically intermediate languages, i.e. languages which exhibit both stresstimed and syllable-timed properties. One such example is Polish, a language with complex syllable structure but no phonological vowel reduction (Patel 2008: 124). Therefore, it is especially interesting how Polish speech and music will score in relation to English, applying the methodology proposed by Patel and Daniele.

Rather than focusing on the stress-time and syllable-time debate, a much more important matter is the fact that there are measurable differences between languages and one can find acoustic correlates of language rhythm in the speech signal. Roach (1982) claims that languages labelled as stress-timed allow complex consonant clusters, leading to higher variation of consonant clusters, and vowel reduction, leading to higher variation of vocalic intervals. The result of this observation is the nPVI by Grabe and Low (2002): a measure of temporal patterning in speech used for comparing stress-timed and syllable-timed languages by calculating the degree of durational contrast between successive elements in a sequence.

$$
\mathrm{nPVI}=\frac{100}{m-1} \times \sum_{k=1}^{m-1}\left|\frac{d_{k}-d_{k+1}}{\frac{d_{k}+d_{k+1}}{2}}\right|
$$

Figure 1. nPVI (after Patel and Daniele 2003: 37).

In Figure 1, $m$ is the number of vocalic intervals present in an utterance, while $d k$ is the duration of the $k$ th interval. When measuring the nPVI for a given utterance, larger contrasts between neighbouring durations result in higher nPVI values. According to the study by Ramus (2002), languages often labelled 'stress-timed' receive higher nPVI results due to high variation of consonant clusters and vowel reduction, while languages often labelled 'syllable-timed' obtain lower nPVI values due to the absence of such features and a relatively stable duration of neighbouring syllables. In Figure 2, the results of this analysis show that stress-timed English and Dutch are contrasted with syllable-timed Spanish, Catalan, Italian or French. Polish is a particularly interesting case, as it 
shares features of both stress-timed and syllable-timed languages: it has a relatively high intervocalic rPVI (raw Pairwise Variability Index, not rate normalised) due to a complex syllable structure, and the lowest vocalic nPVI score from all of the languages studied, primarily due to no phonological vowel reduction.

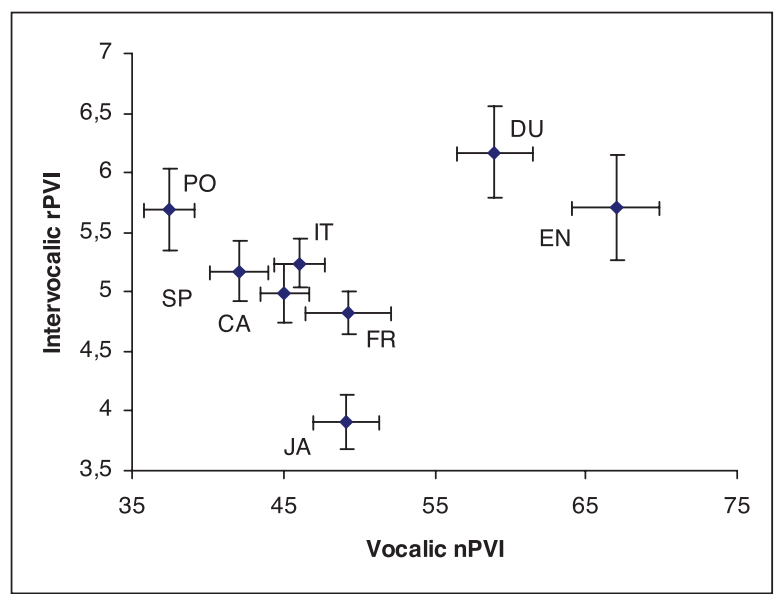

Figure 2. Intervocalic rPVI vs. vocalic nPVI in the RNM corpus (after Ramus 2002: 117).

In their study, Patel and Daniele (2003: 37) argue that the nPVI can be successfully used for measuring musical themes as well, since it is a relative measure of variability, i.e. "the durational difference between each pair of intervals is measured relative to the average length of the pair", and musical tones represented by notes, just like vowels in speech, are core units in a rhythmic pattern. They compared a set of recorded English and French news-like sentences with musical themes taken from instrumental pieces of classical 19th-century composers. The results presented in Figure 3 show that the average differences between languages are paralleled by musical differences. Indeed, Patel and Daniele broke new ground in interdisciplinary research, which needs to be further inspected across other languages and musical genres. 

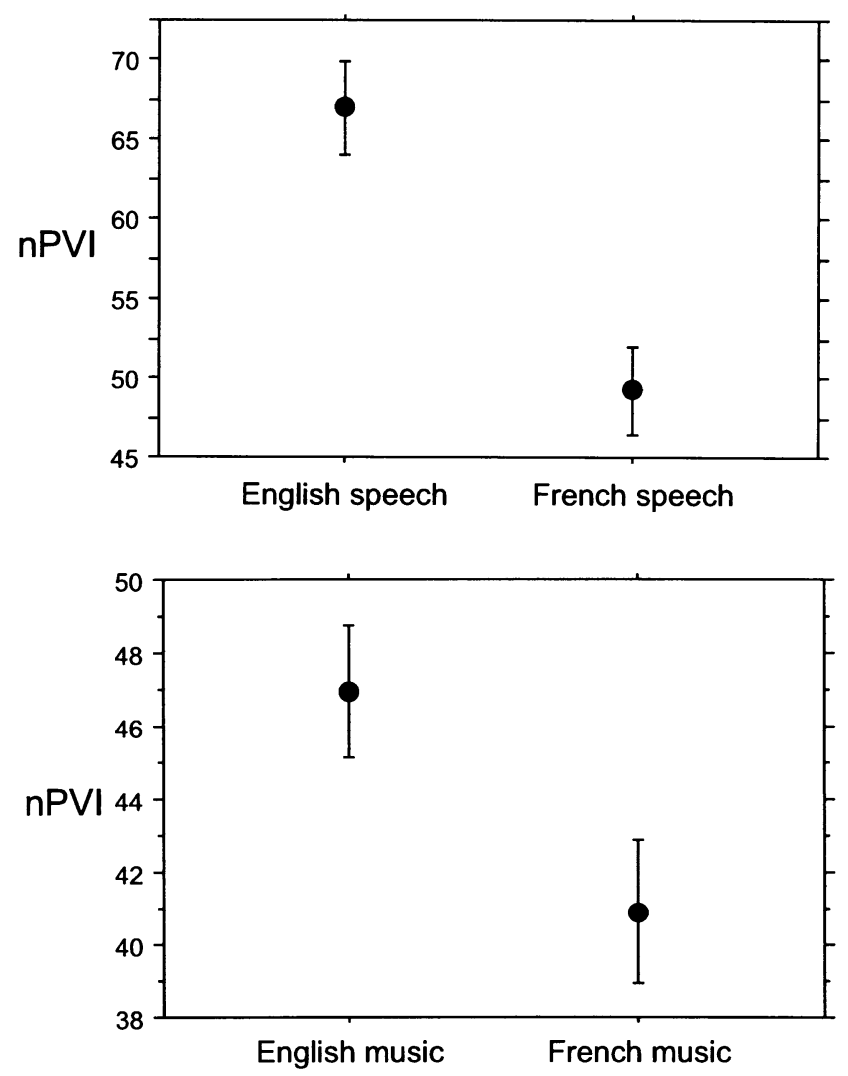

Figure 3. nPVI values for English and French sentences and musical themes (after Patel and Daniele 2003: 38-41).

\section{The study}

\subsection{Introduction}

Although the study by Patel and Daniele (2003) provides an original, interdisciplinary approach to studying the relationship between linguistic and musical rhythm, it raises more questions than it provides answers: Will this method produce the expected results for other languages? Is it possible to investigate other musical genres? The aim of this study is to verify the method in question by introducing modifications in the choice of linguistic and musical samples. 
First, the languages selected for comparison are English and Polish, where the former is considered as an prototypical stress-timed language, while the latter is an example of a mixed-type language, which is difficult to assess according to the traditional rhythmic classification. Indeed, while French, a typical syllable-timed language, served as a good counterexample in the study by Patel and Daniele, the choice of a rhythmically intermediate language can bring unexpected results. However, if extrapolating from the study by Ramus (2002), where English had the highest nPVI result, while Polish, on the other hand, had the lowest, it might be assumed that the observed difference between English and Polish should be reflected in a similarly great difference between English and Polish music.

Secondly, it is difficult to say whether the method proposed by Patel and Daniele is applicable to all musical forms. In the original study, the authors investigated solely classical music from the 19th c., defined by musicologists as the period of musical nationalism, when the composers attempted to reflect the language and culture of their nations in their works. Consequently, the choice of that particular form of music might be the main reason for obtaining the expected results. Therefore, apart from classical instrumental themes, the author of this study decided also to study a selection of folk melodies. While classical music is a formally taught musical genre governed by strict rules and often analysed through formal theories (e.g. Lerdahl and Jackendoff, 1983), folk music is by definition traditional and performed in most cases by musicians without any formal training. Therefore, it might be assumed that the relationship between linguistic and musical rhythm should be more evident when comparing speech with folk music, a more natural form of expression, not restricted by formal teaching or theoretical formulas. The study will hopefully shed more light on the language-music subject and examine the versatility and reliability of the method developed by Patel and Daniele for future interdisciplinary studies. Most importantly, however, the study will test whether the linguistic rhythm conventionalised in the language of a community affects the rhythm in the classical and folk musical practice of that community.

\subsection{Data}

The speech corpus consisted of 20 English and Polish sentences recorded at the Centre for Speech and Language Processing at the Faculty of English, Adam Mickiewicz University. The speakers were one Polish (Szczecin, Zachodniopo- 
morskie) and one English (Leeds, West Yorkshire) adult male native speaker, both of whom work as academic instructors. The sentences comprised of short, news-like utterances read in a neutral tone of voice. The English sentences were taken from Nazzi et al. (1998), which were also used in Patel and Daniele (2003), while the Polish sentences were prepared by the author of this study to resemble the English sentences in terms of length and number of vowels.

The speech corpus was analysed in Praat (Boersma and Weenink 2013) and vowel measurements were taken by following the suggestions outlined in Thomas (2011: 138-45). The nPVI measurements were taken using an online nPVI calculator provided by the Neuroscience Institute, California (http://www.nsi.edu/ ani/npvi_calculator.html/). Table 1 presents example sentences from the English and Polish corpora used in the study. A complete list of recorded sentences is included at the end of this paper.

Table 1. Examples of sentences used to compute linguistic nPVI values.

English

A hurricane was announced this afternoon on the TV.

The committee will meet this afternoon for a special debate.

This supermarket had to close due to economic problems.

Polish

Straż pożarna dostała zgloszenie o pożarze pociagu.

Sąd uznat, że nie ma cienia watpliwości, że doszło do złamania prawa.

Jego zdaniem dziennikarze nie powinni angażować się politycznie.

The music corpus was divided into two categories: the classical music corpus comprised of a selection of 19th-century English and Polish instrumental themes, while the folk music corpus comprised of a set of traditional English and Polish folk songs. The selection of English and Polish classical composers was based on the classification of their works by musicologists as examples of musical nationalism, a 19th-century musical movement considered to reflect the language and culture of a nation (Grout and Palisca 2000). The English folk music corpus was based on Child Ballads, a collection of English traditional songs accumulated by Francis James Child during the second half of the 19th century. 
A collection of folk songs by Luboff and Stracke (1969) served as an additional reference for music notation. The Polish folk music corpus was based entirely on Pieśni Ludu Polskiego, compiled by Oskar Kolberg in 1857.

The selected classical themes were predominantly main melodic themes that occur chiefly at the beginning of the compositions, while folk themes were predominantly main melodies played in the chorus of each song. One main theme of a length of usually four bars was taken from each composition. The nPVI results were obtained directly from music notation. Figures 4 and 5 present example musical themes with nPVI calculations. The music scores were edited using noteflight (http://www.noteflight.com/).

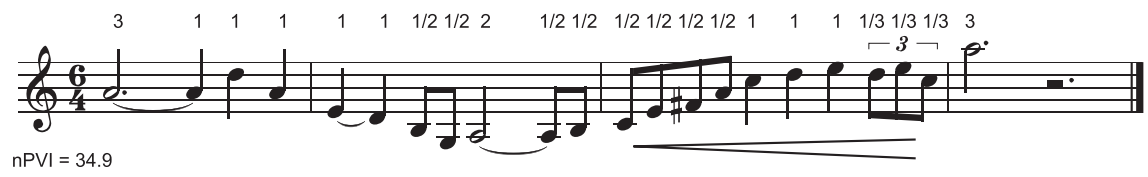

Figure 4. Duration coding and nPVI calculations of Sonata for Violin and Piano by Frederic Delius.

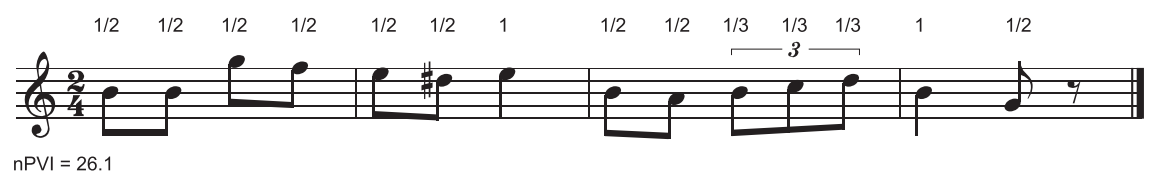

Figure 5. Duration coding and nPVI calculations of a Polish folk song Na Podolu Biały Kamień.

Following Patel and Daniele, durations were assigned to the notes according to the time signature of each musical piece. The basic beat was given a duration of 1 , while the durations of the following notes were calculated as multiples or fractions of that note depending on their length according to standard music notation conventions. To illustrate, a quarter note in $4 / 4$ was given a duration of 1 , a half note a duration of 2 , an eighth note a duration of $1 / 2$, etc. The obtained durations were used to calculate the nPVI for each musical theme using the same nPVI calculator as for the speech segment. A total of 20 classical and 20 folk musical themes were analysed for both Polish and English. 
The reason for relying on music notation rather than live performances was similar to the one given by Patel and Daniele, as it would be difficult to determine which recordings should be regarded as the closest to the composer's intention. Therefore, music notation can be regarded as "an unambiguous record of the composer's choice of relative note durations" (2003: 40). A complete list of composers and musical themes is included at the end of this article. Table 2 presents a summary of all the data used in the study.

Table 2. Data summary.

\begin{tabular}{lll}
\hline & English & Polish \\
\hline Total vowels & 310 & 386 \\
No. vowels/sentence mean & 15.5 & 19.3 \\
Classical, total notes & 364 & 362 \\
Classical, no. notes/theme mean & 18.2 & 18.1 \\
Folk, total notes & 327 & 353 \\
Folk, no. notes/theme mean & 16.4 & 17.7 \\
\hline
\end{tabular}

\section{Results}

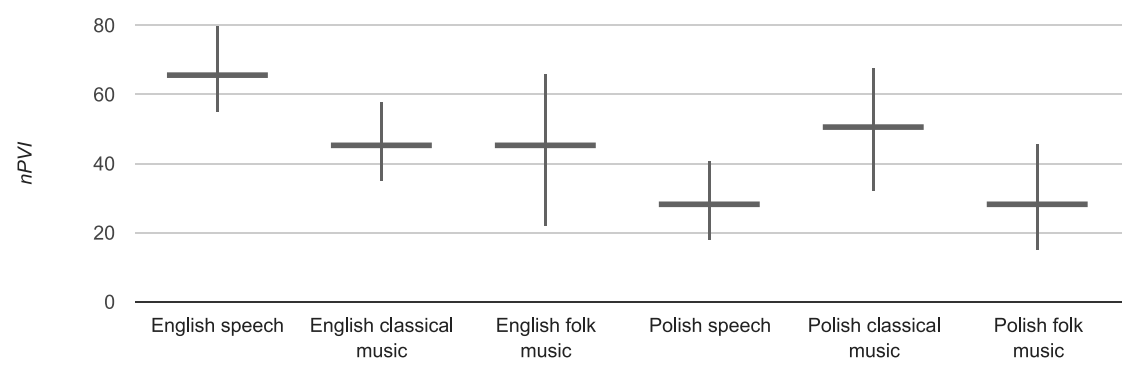

Figure 6. nPVI values for English and Polish speech, classical music themes and folk music themes. 
Figure 6 presents the results of the linguistic and musical nPVI measurements for English and Polish. Firstly, the mean values for English and Polish speech are different, with English speech having a greater value (mean $\mathrm{nPVI}=66.1$ ) than Polish (33.8). These results are similar to the ones found in Ramus (2002), where the former language has the highest nPVI score, while the latter has the lowest out of all eight languages measured. Surprisingly, English and Polish classical music do not share the same tendency, on the contrary, the mean nPVI for English themes is slightly lower than for the Polish ones (46.1 vs. 51.0). However, the score for Polish classical themes is very close to the nPVI data in Appendix 2 in Patel (2008: 178), which lists the nPVI of Polish classical musical themes as 50.2, based on 60 themes from The Dictionary of Musical Themes. Finally, the results for folk music are in agreement with Patel's theory: the nPVI for English folk music themes are higher than for Polish (46.1 vs. 29.1).

The nPVI for English speech ranged from 55 to 80, while for Polish it ranged from 18 to 41. In classical music, nPVI for English themes ranged from 35 to 58, while for Polish it ranged from 33 to 68. Although the most arguable choice might be Fryderyk Chopin, a Polish composer who spent most of his adult life in France, the nPVI results for his musical themes alone were not different from the mean value (from 42 to 53). Finally, the nPVI for English folk music themes ranged from 22 to 66, while for Polish it ranged from 15 to 46 .

Although the results present an intriguing relationship between speech and music, the relatively small sample cannot be recognised as sufficient enough to form any firm conclusions. However, the primary aim of the study was to acknowledge the importance of implementing other musical genres to the ongoing debate of the use of the nPVI in the study of linguistic and musical rhythm. The results show that the nPVI can be quite different for classical and folk music, not only having different values but also altered tendencies. While the classical music scores are different from the study by Patel and Daniele, the results for folk music suggest that the incorporation of less formal and more traditional musical genres yields a new insight into the language-music discussion.

\section{Conclusions}

The aim of the experiment was to test whether the linguistic rhythm conventionalised in the language of a community affects the rhythm in the musical practice of that community on the example of English and Polish speech and classical, as well as folk music. The hypothesis, based on the study by Patel and 
Daniele, was neither clearly falsified, nor clearly confirmed. While the relationship between speech rhythm and classical music rhythm was not corroborated, the link between speech and folk music seems more apparent. The study, however, did not investigate the relationship between linguistic and musical rhythm per se, but specifically if the linguistic rhythmic conventions have a bearing on musical practice. Therefore, the results of the study might suggest that there is greater interference between speech and traditional folk music rather than between speech and formalised classical works.

Indeed, finding a perfect empirical tool for studying rhythm in language and music can be a perplexing task. To begin with, there is still a lack of one generally accepted quantitative method for measuring rhythmic phenomena. Although the $\mathrm{nPVI}$ is a relatively popular tool for such studies, the issues with standard definitions of speech rate, as originally pointed out by Ramus (2002), are still valid. It is not clear whether syllables, phonemes, feet or vocalic intervals should be considered as the ultimate units for rhythmic measurements. Likewise, measuring musical rhythm can be equally demanding: selecting themes that will have similar duration, tempo and the higher level rhythmic structure needs to be addressed in future studies. Moreover, choosing one unit for all languages or musical genres can be considered as a problematic case, as normalisation can lead to omitting cross-linguistic differences in rhythm. Hence, it is crucial to take into account a wider range of speakers and musical pieces, obtain the nPVI results for different units and assess the speech rate and tempo of the analysed corpora.

Although the study by Patel and Daniele is an original approach for comparing linguistic and musical rhythm, it still requires improvements in order to obtain more clearly interpretable results. London and Jones (2010: 379) argue that "musical rhythm is highly hierarchic in nature" and suggest to inspect the nPVI on higher levels of rhythmic structure, assess the metrical types and determine the relationship between surface and higher-level nPVI. They conclude that the results can be more complex and may require larger corpora, including a broad range of musical genres.

This experiment confirmed that studying linguistic and musical rhythm is indeed a complex phenomenon that cannot be easily categorised. Although the nPVI results for speech samples are comparable to previous research, the results for classical and folk music are more problematic. Although Patel and Daniele provided rules for choosing musical themes for their analysis, the choices are still relatively arbitrary, having little or no regard to higher level rhythmic struc- 
tures, tempo or length of the selected pieces. One possible solution to this problem could be a preparation of the database with speech samples and musical themes of equal number of vowels/notes, speech rate/tempo and duration. Secondly, the use of recordings of live performances over music notation might bring more natural results, not restricted by the absolute values of musical notes. Finally, a cross-dialectal analysis might be more accurate for a general crosslinguistic study, as folk music themes can differ significantly depending on the region of their origin, while classical composers can be similarly influenced by regional accents and music.

To conclude, this preliminary study confirms the need to investigate the phenomenon of rhythm in language and music, suggesting that linguistic rhythm can indeed influence musical rhythm, as it can be observed across different languages and various musical genres. However, since this study was a reproduction of the original research by Patel and Daniele, it also repeated its imperfections, which become more apparent. Hopefully, the results and the methodological suggestions that followed will be applied in future studies in order to further examine the influence of linguistic rhythm on musical practice and test other languages and musical genres. 


\section{Appendix A. English and Polish sentences}

A hurricane was announced this afternoon on the TV. Finding a job is difficult in the present economic climate. Having a big car is not something I would recommend in this city. In this case, the easiest solution seems to appeal to the court. In this famous coffee shop you will eat the best donuts in town. Much more money will be needed to make this project succeed. My grandparent's neighbour's the most charming person I know. No welcome speech will be delivered without the press offices' agreement. Science has acquired an important place in western society. The city council has decided to renovate the Medieval centre. The committee will meet this afternoon for a special debate. The government is planning a reform of the education program. The last concert given at the opera was a tremendous success. The library is open every day from eight $\mathrm{a}$. $\mathrm{m}$. to six $\mathrm{p}$. $\mathrm{m}$. The local train left the station more than five minutes ago. The parents quietly crossed the dark room and approached the boy's bed. They didn't hear the good news until last week on their visit to their friends. This rugby season promises to be a very exciting one. This supermarket had to close due to economic problems. This year's Chinese delegation was not nearly as impressive as last year's.

Biuro podróży zobowiązało się do pokrycia kosztów transportu. Ekipa naukowców wykorzystała w badaniach techniki medycyny sądowej. Fundacja od wielu lat postulowała wykreślenie tego przepisu. Innym dziennikarzom nie wolno zadawać żadnych pytań. Jego zdaniem dziennikarze nie powinni angażować się politycznie. Mężczyzna został doprowadzony do policyjnego aresztu. Musimy rozważyć alternatywne teorie powstawania planet. Na razie nie wiadomo, które z miast zgłosi swoją kandydaturę. Naukowcy muszą opracować nową metodę wydobycia szczątków. Podczas upałów trzeba odsłonić jak największą powierzchnię ciała. Posłowie powinni mieć obowiązek pracy nad nowymi ustawami. Rośnie liczba turystów spędzających wczasy za granicą. Sąd uznał, że nie ma cienia wątpliwości, że doszło do złamania prawa. Straż pożarna dostała zgłoszenie o pożarze pociągu. Szanse na miejsce w pierwszej czwórce są już tylko iluzoryczne. W pełnym słońcu odczuwalna temperatura wynosi ponad 40 stopni. W tym roku uroczystość oprotestowała grupa radnych. Władze wprowadziły dzisiaj stan wyjątkowy i godzinę policyjną. Zamiar wzięcia udziału $\mathrm{w}$ głosowaniu zadeklarowało 50 proc. badanych. Zmuszanie się do kaszlu niczego dobrego nam nie przyniesie.

\section{Appendix B. English and Polish classical composers and musical themes}

Arnold Bax (1883-1953): Fantasy Sonata, First Sonata For Viola And Piano, Piano Sonata No.1, Second Sonata For Viola And Piano, Sonata For Viola And Piano; Frederick Delius (1862-1934): Cello Sonata, Piano Concerto, Sonata For Violin And Piano, Violin Concerto; Edward Elgar (1857-1934): Concerto For Violin and Orchestra, Op. 61, Pastourelle For Violin And Pianoforte, Sonatina For Piano, Symphony No. 1, in A 
Flat, Opus 55, Violin Sonata, Op.82; Gustav Holst (1874-1934): The Planets; John Ireland (1879-1962): Piano Sonatina, Violin Sonata No.1 in D minor, Violin Sonata No.2 in A minor; Ralph Vaughan Williams (1872-1958): A London Symphony, Sonata in A Minor For Violin And Piano Forte.

Fryderyk Chopin (1810-1849): Krakowiak Op. 14 No. 1, Mazurka Op. 6 No. 1, Piano Concerto Op. 11 No. 1, Piano Sonata No. 1 Op. 4 , Polonaise Op. 26 No. 1; Ignacy Jan Paderewski (1860-1941): Krakowiak Op. 5 No. 1, Mazurka Op. 5 No. 1, Piano Sonata Op. 21 No. 1, Polonaise in B major Op. 9 No. 6; Karol Szymanowski (1882-1937): Mazurka Op. 62 No. 1, Violin Concerto, Op. 35 No. 1, Violin Sonata, Op. 9 No. 1; Henryk Wieniawski (1835-1880): Kujawiak Op. 3 No. 1, Mazurka Op. 19 No. 2, Polonaise Op. 21 No. 1, Violin Concerto Op. 14 No. 1; Juliusz Zarębski (1854-1885): Ballade Op. 18 No. 1, Mazurka Op. 8 No. 1, Polonaise Op. 10 No. 1; Władysław Żeleński (1837-1921): Mazurka Op. 31 No. 1.

\section{Appendix C. English and Polish folk songs}

Barbara Allen, Edward, Geordie, Ilkley Moor Baht Hat, Lincolnshire Poacher, Little Wee Croodin Doo, My Boy Willie, O, Sally My Dear, One Man Shall Mow My Meadow, Poor Old Horse, Riddles Wisely Expounded, Robin Hood And The Tanner, Tam Lin, The Cuckoo Is A Pretty Bird, The Elfin Knight, The Friar in the Well, The Seeds Of Love, The Three Ravens, The Trees They Grow So High, The Vicar Of Bray.

A W Krakowie Na Ulicy, Bywaj Zdrowa i Szczęśliwa, Czego Kalinko W Dole Stoisz, Deszczyk Pada, Słońce Grzeje, Gdybym To Ja Miała, Graj Pastuszku Graj, Haniu Moja, Jasio Konie Poit, Koło Dworu Topola Stojała, Na Podolu Biaty Kamień, Oj Miałem Dobre Woty, Stużyt Stuga U Pana, Sniło Się Marysi, Stała Nam Się Nowina, Tam Za Warszawa Na Błoniu, UMej Matki Rodzonyj, Wezme Ja Kontusz, Wyjechat Pan Z Chartami W Pole, Zaszumiała Leszczyna, Zielona Łaczka. 


\section{References}

Abercrombie, D. 1967. Elements of general phonetics. Chicago, IL: Aldine.

Abraham, G. 1974. The tradition of Western music. Berkeley, CA: University of California Press.

Boersma, P. and D. Weenink. 2013. "Praat: doing phonetics by computer". (Computer programme). Version 5.3.56, retrieved $15 \mathrm{Sep} 2013$ from $<\mathrm{http}$ ://www.praat.org/>.

Child, F. J. 1882-1898. The English and Scottish popular ballads. Boston: Houghton Mifflin.

Darwin, C. 1871. The descent of man, and selection in relation to sex. London: John Murray.

Dauer, R. M. 1983. "Stress-timing and syllable-timing reanalyzed". Journal of Phonetics $11.51-62$.

Dellwo, V. 2006. "Rhythm and speech rate: A variation coefficient for deltaC". In: Karnowski, P., I. Szigeti and P. Lang (eds.), Language and language-processing. Proceedings of the 38th Linguistic Colloquium, Frankfurt am Main. 231-241.

Grabe, E. and E. L. Low. 2002. "Durational variability in speech and the rhythm class hypothesis". Laboratory Phonology 7. 515-546.

Grout, D. J. and C. V. Palisca. 2000. A history of Western music. (6th edn.) New York: W. W. Norton.

Handel, S. 1989. Listening: An introduction to the perception of auditory events. Cambridge, MA: MIT Press.

Kolberg, O. 1857. Dzieła wszystkie, tom I: Pieśni ludu polskiego. Polskie Towarzystwo Ludoznawcze.

Lerdahl, F. and R. Jackendoff. 1983. A generative theory of tonal music. MIT Press, Cambridge.

Liberman, M. 1975. "The intonational system of English". (PhD thesis, MIT.)

London, J. and K. Jones. 2010. "Metrical hierarchies and musical nPVI: A re-analysis of Patel and Daniele", Proceedings of the 11th International Conference on Music Perception and Cognition. 379-380.

Luboff, N. and W. Stracke. 1969. Songs of man: The international book of folk songs. Englewood Cliffs, NJ: Prentice-Hall.

McGowan, R. W. and A. G. Levitt. 2011. "A comparison of rhythm in English dialects and music". Music Perception 28(3). 307-313.

Mithen, S. 2005. The singing Neanderthals: The origins of music, language, mind and body. London: Weidenfeld and Nicolson.

Nazzi, T., J. Bertoncini and J. Mehler. 1998. "Language discrimination in newborns: Toward an understanding of the role of rhythm". Journal of Experimental Psychology: Human Perception and Performance 24(3). 756-777.

Nespor, M. 1990. "On the rhythm parameter in phonology”. In: Rocca, I. (ed.), Logical issues in language acquisition. 157-175. Dordrecht: Foris.

Nettl, B. 2000. "An ethnomusicologist contemplates universals in musical sound and musical culture". In: Wallin, N. L., B. Merker and S. Brown (eds.), The origins of music. Cambridge, MA: MIT Press. 463-472. 
Patel, A. D. 2006. "Musical rhythm, linguistic rhythm, and human evolution". Music Perception 24. 99-104.

Patel, A. D. 2008. Music, language, and the brain. New York: Oxford University Press.

Patel, A. D. and J. R. Daniele. 2003. "An empirical comparison of rhythm in language and music". Cognition 87. 35-45.

Pike, K. N. 1945. The intonation of American English. Ann Arbor: University of Michigan Press.

Ramus, F. 2002. "Acoustic correlates of linguistic rhythm: Perspectives”. Proceedings of Speech Prosody. 115-120.

Roach, P. 1982. "On the distinction between 'stress-timed' and 'syllable-timed' languages". In: Crystal, D. Linguistic controversies: Essays in linguistic theory and practice in honour of F. R. Palmer. London: Hodder Arnold. 73-79.

Selkirk, E. O. 1984. Phonology and syntax: The relation between sound and structure. Cambridge, MA: MIT Press.

Thomas, E. R. 2011. Sociophonetics: An introduction. Palgrave Macmillan.

Wallin, N. L., B. Merker and S. Brown. (eds.). 2000. The origins of music. Cambridge, MA: MIT Press.

Wenk, B. J. 1987. "Just in time: On speech rhythms in music". Linguistics 25. 969-981.

\author{
Address for correspondence \\ Mateusz Jekiel \\ Faculty of English \\ Adam Mickiewicz University \\ Collegium Novum \\ al. Niepodległości 4 \\ 61-874 Poznań \\ Poland \\ mjekiel@wa.amu.edu.pl
}

